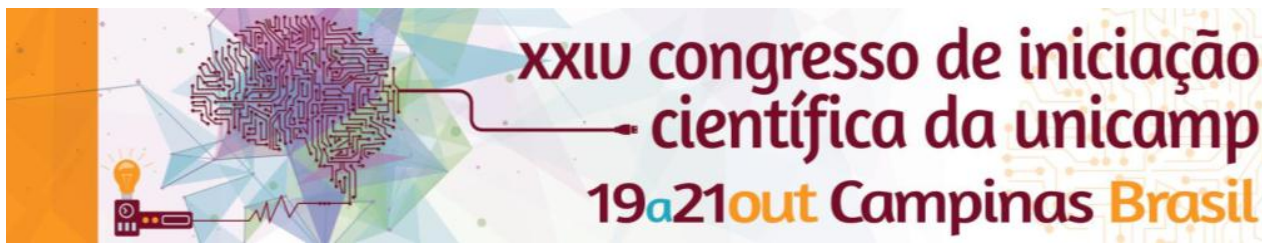

\title{
Jacinto Heller: Repertório de um empresário teatral (1875-1885)
}

\author{
Aléxia Lorrana S. Ferreira* \\ Orientação: Profa. Dra. Larissa de Oliveira Neves
}

\section{Resumo}

O trabalho é fruto de um levantamento de dados, feito em periódicos do século XIX, sobre a trajetória da empresa teatral Phênix Dramática, empresariada por Jacinto Heller, buscando registros sobre as peças encenadas entre $1875 \mathrm{e}$ 1885. Incluindo, também, um panorama das circunstâncias e contextos históricos em que a companhia estava inserida.

\section{Palavras-chave:}

Teatro musicado, Companhia Phênix Dramática, História do teatro brasileiro.

\section{Introdução}

Em 1859, com a criação do Teatro Alcazar Lyrique, no Rio de Janeiro, pelo empresário Joseph Arnaud, inicia-se no país um momento de popularização do teatro musicado. Esse teatro de entretenimento significou uma mudança de concepção estética e um marco na recepção das operetas europeias pelos autores brasileiros. Estes se viram estimulados a traduzir, adaptar, parodiar e escrever esse tipo de peça que tanto chamava a atenção do público do Rio de Janeiro. Público que só aumentava e, atraído pelas músicas, danças, pela beleza das atrizes e pela visualidade de um modo geral, contribuiu para intensificar os benefícios financeiros para autores, atores e empresários. Apesar de todo esse sucesso, o teatro ligeiro foi alvo de muita crítica pelos intelectuais e letrados da época. Preferindo a dramaturgia do chamado teatro sério, eles queixavam-se e expressavam suas decepções com os novos rumos do teatro nas páginas dos jornais. No entanto, a consolidação do gênero ligeiro foi um impulso para a vida teatral do Rio de Janeiro.

Jacinto Heller (1834-1909), à frente da Companhia Phênix Dramática, foi o principal responsável pela divulgação dos primeiros gêneros de teatro musicado, transformando-se rapidamente em concorrente direto do Teatro Alcazar Lyrique. Evidenciando a participação e contribuição de Jacinto Heller no cenário teatral do século XIX, e também observando o quanto os sucessos de suas montagens tornaram sua companhia a principal produtora dos gêneros musicais e ligeiros nos anos 1870 e 1880, essa pesquisa, através de fontes primárias, como anúncios, programas, e crítica de espetáculos publicados em jornais, fez um levantamento da trajetória de sua empresa teatral.

\section{Resultados e Discussão}

A partir de buscas utilizando palavras-chave, na imprensa diária do Rio de Janeiro entre 1875 e 1885, e utilizando a Gazeta de Notícias como principal periódico, foram encontrados diversos anúncios de espetáculos da empresa de Jacinto Heller. Estes dados foram separados e devidamente tabulados, de modo a registrar quais peças foram encenadas pela companhia. Dispondo de uma equipe grandiosa, que contava com atores consagrados da época, como Vasques, Guilherme de Aguiar, Mattos, Rose Villiot e Delmary, a companhia
Phênix Dramática encenou, nesses dez anos, cerca de cento e quarenta peças diferentes: em torno de quarenta e cinco operetas, trinta e cinco comédias, quinze cenas cômicas, dez dramas, dez mágicas e outros tantos espetáculos sem gênero identificado.

O teatro musicado foi estruturando-se como a principal forma de diversão urbana, voltado para o grande público - formado por uma gama heterogênea de indivíduos, que iam de escravos até a família real. Esse tipo de teatro investia na espetacularidade cênica, sem se preocupar com o teatro edificante, e tornava a "indústria"1 do teatro musical um campo de diálogo e confrontos culturais, propulsor de sua popularidade. E é devido a seu forte apelo popular, e sua "imoralidade", que foi tão criticado e considerado, pelos intelectuais da época, um gênero menor, ligando-o totalmente a uma suposta decadência do teatro nacional.

Figura 1. - Jacinto Heller.

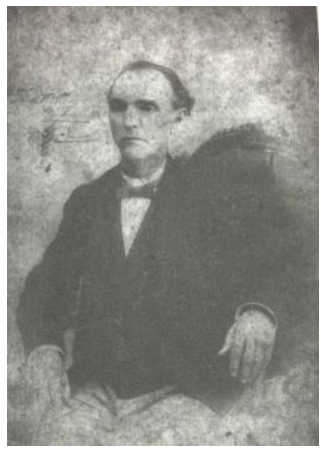

\section{Conclusões}

Houve grande crescimento da vida teatral no Rio de Janeiro nesse período. Jacinto Heller teve papel fundamenta nesta história. Este tipo de teatro popular vai influenciar o rumo das produções teatrais posteriores, contribuindo não só para a construção do teatro nacional pautado na espetacularidade e no contato com o popular, como também na produção de uma dramaturgia moderna.

\footnotetext{
${ }^{1}$ MENCARELLI, Fernando. A voz e a partitura: teatro musical, indústria e diversidade cultural no Rio de Janeiro (1868-1908). Tese (Doutorado em História). Campinas, IFCH/Unicamp, 2003.
} 